\title{
Association between Self-esteem Levels of University Female Students and Their Special Abilities and Achievements
}

\author{
Neha Sharma ${ }^{1}$ and Vishala Patnam ${ }^{2}$ \\ Vasantrao Naik Marathwada Krish Vidyapeeth, Parbhani-431402
}

\begin{abstract}
Fifty five percent of University female students assessed to have middle level self esteem followed by high level self esteem (24.50\%) and low level self esteem (24.50\%), irrespective of SES groups. Significant relationship was found between the self esteem levels of University female students and with their special abilities like oration, painting, sports, cooking, maintenance and decoration of home. And their special achievements in curricular and co-curricular such as merit positions in college, scholarship and receiving prizes in different co-curricular activities irrespective of their SES groups.
\end{abstract}

Key words: Self esteem, Low SES, Middle SES, Special Achievements, Special Abilities.

Self-esteem is a term in psychology to reflect a person's overall evaluation or appraisal of his or her own worth. Self-esteem encompasses beliefs, like I am competent, I am worthy and emotions such as pride, triumph, despair, and shame. The self-concept is what we think about the self, while the self-esteem is the positive or negative evaluation of one's self. In short, it is one's self evaluative perception. Self-esteem is a basic human need or motivation. It is divided into two aspects, the esteem for oneself (self-love, self-confidence, skill, aptitude, etc.), and respect one receives from other people (recognition, success, etc.). Rosenberg defined the self-esteem as a stable sense of personal worth or worthiness. It is also described as the core of self -concept. It is not the facts about one-self but it is what one believes to be true about one-self. It is inclusive of both the descriptive and evaluative self-related statements. Self esteem directly associated with effective personal judgment. Self esteem is the product of two internal assessments or judgments, the global judgment and one's self-worth. Hence self esteem is something that everyone definitely needs for leading quality and happy life. In current era this self esteem topic is given lot of attention by the researchers for findings out the changing trends in its development. So it was felt necessary to assess the self esteem of University female students and its relation with their special abilities and achievements.

\section{Materials and Methods}

A sample of 200 University female students were chosen at random from the 4 colleges of Vasantrao Naik Marathwada Krishi Vidyapeeth Parbhani (MS). Out of the 200 female students, 100 were from the middle SES group and the remaining 100 were from the low SES group. The age group of the students ranged between 17 yrs and 24 yrs. The Self-esteem Scale for Women developed by Kapadiya and Verma was administered on them for assessing their self esteem levels. Kuppuswamy's Socio-economic status scale for urban population revised by Patnam (2010) was used to assess the socio-economic status of sample students. A structured cum open ended interview schedule was developed to elicit the information related to students' background and various aspects of the life.

\section{Results and Discussion}

Table 1 Comparison between self esteem levels of University female students based on their and SES groups

\begin{tabular}{|c|c|c|c|c|}
\hline \multirow{3}{*}{$\begin{array}{c}\text { Classification } \\
\text { of self esteem } \\
\text { levels of } \\
\text { students \& } \\
\text { scores ranges }\end{array}$} & \multirow{3}{*}{$\begin{array}{c}\text { Total } \\
\text { University } \\
\text { Female } \\
\text { Students } \\
(200)\end{array}$} & \multirow{2}{*}{\multicolumn{2}{|c|}{$\begin{array}{c}\text { University female students (200) } \\
\text { Levels of education and socio-economic status }\end{array}$}} & \multirow[t]{3}{*}{$Z$ values } \\
\hline & & & & \\
\hline & & Low(100) & Middle(100) & \\
\hline $\begin{array}{c}\text { High } \\
(107-123) \\
\end{array}$ & $24.50(45)$ & $20.00(20)$ & $25.00(25)$ & $0.84^{\mathrm{NS}}$ \\
\hline $\begin{array}{l}\text { Middle } \\
(86-106)\end{array}$ & $55.00(110)$ & $54.00(54)$ & $56.00(56)$ & $0.28^{\mathrm{NS}}$ \\
\hline $\begin{array}{c}\text { Low } \\
(41-85)\end{array}$ & $24.50(45)$ & $26.00(26)$ & 19.00(19) & $1.18^{\mathrm{NS}}$ \\
\hline
\end{tabular}


Table 1 indicates that 55 percent of University female students assessed to have middle level self esteem followed by high level self esteem (24.50\%) and low level self esteem (24.50\%) irrespective of SES groups. Fifty four to fifty six percent of them irrespective of their SES were rated as having middle level of self esteem followed by low level self esteem female students (19-26) and high level self esteem female students (20-25\%). These results are in agreement with the research findings of Maruyana et al (1981), Francis and Jones (1996) Patnam et al (2007) and also with general notion that majority of the Indian students and women develop middle level of self esteem due to various socio-economic factors.

Table 2 indicates that 25 percent high level self esteem, low SES group, UG female students were found to have special abilities in painting followed by dance (17\%), oration (17\%), sports (17\%), GK (17\%) and singing $(8 \%)$. The corresponding percentages of middle level self esteem UG female students were 14, 23, 18, 23, 14 and 9 and the low level self esteem, UG female students were 6, 6, nil, nil, 19 and 6. Forty two percent of high level self esteem UG female students reported to have special abilities for cooking food followed by maintenance of house $(33 \%)$, decorating house $(17 \%)$ and stitching garments $(8.33 \%)$. The corresponding percentages of middle level self esteem female students were 36, 23, 32 and 9 and the low level self esteem UG female students were 6.50, 6.50, 25 and nil. With regard to middle SES group, UG female students 22 percent high level self esteem female students were found to have special abilities in painting, dance and sports followed by GK $(17 \%)$, oration $(11 \%)$ and singing $(6 \%)$. The corresponding percentages of middle level self esteem UG female students were 25,18,18,41,18 and 16 and the low level self esteem UG female students were 10, nil, nil, 10, 20 and nil. Thirty three percent of high level self esteem UG female students reported to have special abilities for maintenance of house followed by decorating the house (22\%) and cooking food (16\%). The corresponding percentages of middle level self esteem UG female students were 18, 25 and 25 and the low level self esteem were nil, 30 and nil.

Table 2 Comparison of self esteem levels of the undergraduate female students with their special abilities in co-curricular and household domains

\begin{tabular}{|c|c|c|c|c|c|c|c|c|c|}
\hline \multirow{3}{*}{$\begin{array}{c}\begin{array}{c}\text { Special } \\
\text { abilities }\end{array} \\
\begin{array}{c}\text { Co-curricular } \\
\text { domain }\end{array}\end{array}$} & \multicolumn{6}{|c|}{ SES self esteem levels and percentage of the students (100) } & \multicolumn{3}{|c|}{$\mathbf{Z}$ values } \\
\hline & \multicolumn{3}{|c|}{ Low SES (50) } & \multicolumn{3}{|c|}{ Middle SES(50) } & \multirow[b]{2}{*}{ a vs d } & \multirow[b]{2}{*}{ b vs e } & \multirow[b]{2}{*}{ c vs f } \\
\hline & $\begin{array}{l}\text { High } \\
\text { (12) }\end{array}$ & $\begin{array}{l}\text { Middle } \\
\text { (22) }\end{array}$ & $\begin{array}{r}\text { Low } \\
(16)\end{array}$ & $\begin{array}{c}\text { High } \\
\text { (18) }\end{array}$ & $\begin{array}{l}\text { Middle } \\
(22)\end{array}$ & $\begin{array}{r}\text { Low } \\
(10)\end{array}$ & & & \\
\hline Oration & $16.66(2)$ & $18.18(4)$ & - & $11.11(2)$ & $18.18(4)$ & $2(20.00)$ & $0.38^{\mathrm{NS}}$ & - & $1.58^{\mathrm{NS}}$ \\
\hline GK & $16.66(2)$ & $13.60(3)$ & $18.75(3)$ & $16.66(3)$ & $41.66(5)$ & $1(10.00)$ & -- & $2.20^{*}$ & $0.59^{\mathrm{NS}}$ \\
\hline Painting & $25.00(3)$ & $13.60(3)$ & $06.25(1)$ & $22.22(4)$ & $25.00(3)$ & $10.00(1)$ & 0.18 & $1.35^{\mathrm{NS}}$ & - \\
\hline Dance & $16.66(2)$ & $22.72(5)$ & $06.25(1)$ & $22.22(4)$ & $18.18(4)$ & -- & $0.18^{\mathrm{NS}}$ & $1.02^{\mathrm{NS}}$ & $0.35^{\mathrm{NS}}$ \\
\hline singing & $08.33(1)$ & $09.09(2)$ & $06.50(1)$ & $05.55(1)$ & $16.66(2)$ & -- & $0.41^{\mathrm{NS}}$ & $0.33^{\mathrm{NS}}$ & $1.01^{\mathrm{NS}}$ \\
\hline Sports & $16.66(2)$ & $22.72(5)$ & -- & $22.22(4)$ & $18.18(4)$ & -- & $0.32^{\mathrm{NS}}$ & $0.70^{\mathrm{NS}}$ & $1.01^{\mathrm{NS}}$ \\
\hline None & - & - & $62.50(10)$ & - & - & $60.00(6)$ & $\begin{array}{c}0.14^{\mathrm{NS}} \\
-\end{array}$ & $\begin{array}{c}0.33^{N S} \\
-\end{array}$ & $0 . \overline{10^{\mathrm{NS}}}$ \\
\hline $\begin{array}{c}\text { Household } \\
\text { domain }\end{array}$ & & & & & & & a vs d & b vs e & c vs f \\
\hline Cooking & $41.66(5)$ & $36.36(8)$ & $06.50(1)$ & $16.66(3)$ & $25.00(3)$ & - & $1.50^{\mathrm{NS}}$ & $0.79^{\mathrm{NS}}$ & $1.27^{\mathrm{NS}}$ \\
\hline Stitching & $08.33(1)$ & $09.09(2)$ & - & - & - & - & $1.02^{\mathrm{NS}}$ & $1.47^{\mathrm{NS}}$ & - \\
\hline Decoration & $16.66(2)$ & $31.81(7)$ & $25.00(4)$ & $22.22(4)$ & $25.00(3)$ & $30.00(3)$ & $0.41^{\mathrm{NS}}$ & $0.44^{\mathrm{NS}}$ & $0.27^{\mathrm{NS}}$ \\
\hline Maintenance & $33.33(4)$ & $22.72(5)$ & $06.50(1)$ & $33.33(6)$ & $18.18(4)$ & - & - & $0.33^{\mathrm{NS}}$ & $1.01^{\mathrm{NS}}$ \\
\hline None & - & - & $62.50(10)$ & $27.77(5)$ & $54.54(12)$ & $70.00(7)$ & $2.58 * *$ & $5.08 * *$ & $0.42^{\mathrm{NS}}$ \\
\hline
\end{tabular}

Figures in parentheses indicate number of female students

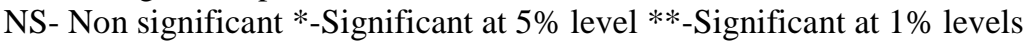

From table 3 it is interesting to note that in low SES group 25 percent of high level self esteem PG female students reported to have special abilities in oration and sports followed by GK (12.50\%), painting $(12.50 \%)$, dance $(12.50 \%)$ and singing (12.50\%). Its corresponding percentages of middle level self esteem PG female students were 6, 25, 3, 22, 22 and 6 and the low level self esteem PG female students were nil, nil, 10, 20, nil, 20 and 10. With respect to the special abilities associated to household domain, 37 percent of high level self esteem PG female students of low SES group reported to have special abilities in cooking food followed by decoration of home (25\%), maintenance of home (25\%) and stitching garments (12\%). With regard to middle SES group PG female students, 43 percent high level self esteem PG female students found to have special ability in oration followed by sports $(29 \%)$, GK $(14 \%)$ and dance $(14 \%)$. Its corresponding percentages of middle level self esteem were 6, 29, 6 and 26 and of the low level self esteem PG female students were nil, 11, nil, 22. With respect to special abilities in household domain, 29 percent of high level self esteem level PG female students reported to have special abilities in cooking food and stitching garments followed by maintenance of house (14.28\%). It is obvious from the results of analysis done within the self esteem levels of University female students in relation to their various special abilities that special abilities like oration, painting, sports, cooking food, maintenance and decoration of home found to positive significant influence on the PG female students' self esteem levels. These findings are in line with research findings of Campbell (2003). 
Table 3 Comparison between self esteem levels of the postgraduate female students with their special abilities in co-curricular and household domains

\begin{tabular}{|c|c|c|c|c|c|c|c|c|c|}
\hline \multirow{3}{*}{$\begin{array}{c}\begin{array}{c}\text { Special } \\
\text { abilities }\end{array} \\
\begin{array}{c}\text { Cocurricular } \\
\text { Domain }\end{array} \\
\end{array}$} & \multicolumn{6}{|c|}{ SES, self esteem levels and percentage of the students (100) } & \multirow{2}{*}{\multicolumn{3}{|c|}{ Z Values }} \\
\hline & \multicolumn{3}{|c|}{ Low SES (50) } & \multicolumn{3}{|c|}{ Middle SES(50) } & & & \\
\hline & $\begin{array}{l}\text { High } \\
(8)\end{array}$ & $\begin{array}{c}\text { Middle } \\
\text { (32) }\end{array}$ & $\begin{array}{l}\text { Low } \\
(10)\end{array}$ & $\begin{array}{c}\text { High } \\
(7)\end{array}$ & $\begin{array}{c}\text { Middle } \\
(\mathbf{3 4})\end{array}$ & $\begin{array}{l}\text { Low } \\
(9)\end{array}$ & a vs d & b vs e & c vs f \\
\hline Oration & $25.00(2)$ & $06.25(2)$ & - & $42.85(3)$ & $05.88(2)$ & - & $0.70^{\mathrm{NS}}$ & $0.17^{\mathrm{NS}}$ & - \\
\hline GK & $12.50(1)$ & $03.12(1)$ & $20.00(1)$ & $14.28(1)$ & $05.88(2)$ & 11.11(1) & $0.11^{\mathrm{NS}}$ & $0.19^{\mathrm{NS}}$ & $0.55^{\mathrm{NS}}$ \\
\hline Painting & $12.50(1)$ & $21.87(7)$ & - & - & $23.52(8)$ & $22.22(2)$ & $1.04^{\mathrm{NS}}$ & $0.25^{\mathrm{NS}}$ & $1.59^{\mathrm{NS}}$ \\
\hline Dance & $12.50(1)$ & $21.87(7)$ & $20.00(2)$ & $14.28(1)$ & $26.47(9)$ & $22.22(2)$ & $0.11^{\mathrm{NS}}$ & $0.19^{\mathrm{NS}}$ & $0.10^{\mathrm{NS}}$ \\
\hline Singing & $12.50(1)$ & $06.25(2)$ & $10.00(1)$ & - & $02.94(1)$ & 11.11(1) & $1.04^{\mathrm{NS}}$ & $0.48^{\mathrm{NS}}$ & $0.07^{\mathrm{NS}}$ \\
\hline Sports & $25.00(2)$ & $25.00(8)$ & - & $28.57(2)$ & $29.41(10)$ & - & $0.13^{\mathrm{NS}}$ & $1.10^{\mathrm{NS}}$ & - \\
\hline None & - & $15.62(5)$ & $50.00(5)$ & - & $05.88(2)$ & $33.33(3)$ & - & $1.36^{\mathrm{NS}}$ & $0.76^{\mathrm{NS}}$ \\
\hline $\begin{array}{c}\text { Household } \\
\text { domain }\end{array}$ & & & & & & & a vs g & b vs h & c vs i \\
\hline Cooking & $37.50(3)$ & $31.25(10)$ & $30.00(3)$ & $28.57(2)$ & $29.41(10)$ & - & $0.37^{\mathrm{NS}}$ & $0.17^{\mathrm{NS}}$ & $2.07 *$ \\
\hline Stitching & $12.50(1)$ & $09.75(3)$ & - & $28.57(2)$ & $05.88(2)$ & 11.11(1) & $0.49^{\mathrm{NS}}$ & $0.63^{\mathrm{NS}}$ & $1.05^{\mathrm{NS}}$ \\
\hline Decoration & $25.00(2)$ & $31.25(10)$ & - & - & $32.35(11)$ & $33.33(3)$ & - & $0.08^{\mathrm{NS}}$ & $2.10^{*}$ \\
\hline Maintenance & $25.00(2)$ & $25.00(8)$ & - & $14.28(1)$ & $14.05(5)$ & 11.11(1) & $0.54^{\mathrm{NS}}$ & $1.13^{\mathrm{NS}}$ & $1.05^{\mathrm{NS}}$ \\
\hline None & - & $31.25(1)$ & $70.00(7)$ & $28.57(2)$ & $17.64(6)$ & $44.44(4)$ & - & $1.34^{\mathrm{NS}}$ & $1.18^{\mathrm{NS}}$ \\
\hline
\end{tabular}

Figures in parentheses indicate number of female students

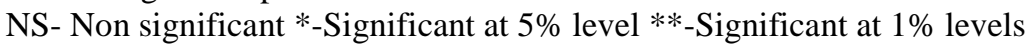

Table 4 indicates that in low SES group 50 percent of the high level self esteem UG female students reported to have got merit positions in their college followed by being scholarship holders $(33.33 \%)$. On the other hand in low SES group 50 percent of the high self esteem UG female students found to have received prizes in sports followed by in dance $(33.33 \%)$ quiz $(17 \%)$ and painting $(17 \%)$. Its corresponding percentages of middle level self esteem UG female students were 27, 9, 18, 36 and 23, and for the low level self esteem UG female students were nil, nil, nil, 12, 12 and 6. Forty one percent middle level self esteem and 88 percent low level self esteem UG female students reported that they did not receive any merit certificates in curricular or co-curricular domains. With regard to middle SES group, 44 percent of high level self esteem UG female students reported to have merit positions in college followed by scholarship holders $(33.33 \%)$ and prize winner in sports $(33 \%)$, dance $(27 \%)$, quiz $(22 \%)$, painting $(22 \%)$ and singing $(16 \%)$. Its corresponding percentages of middle level self esteem UG female students were 36, 9, 18, 27, 41, 14 and 9 and for the low level self esteem were nil, nil, nil, 10, 20, 10 and nil. Thirty one to eighty percent of middle and low level self esteem levels and none of the high level self esteem UG female students of middle SES group reported that they did not have any special achievements in curricular and co-curricular activities.

Table 4 Comparison between self esteem levels of the of undergraduate female students and their special achievements in curricular and co-curricular domain

\begin{tabular}{|c|c|c|c|c|c|c|c|c|c|}
\hline \multirow[t]{3}{*}{$\begin{array}{c}\text { Special } \\
\text { achievements }\end{array}$} & \multicolumn{6}{|c|}{ SES, self esteem levels and Percentage of students (100) } & \multicolumn{3}{|c|}{$Z$ values } \\
\hline & \multicolumn{3}{|c|}{ Low SES (50) } & \multicolumn{3}{|c|}{ Middle SES(50) } & \multirow[b]{2}{*}{ a vs d } & \multirow[b]{2}{*}{ b vs e } & \multirow[b]{2}{*}{ c vs f } \\
\hline & HSE(12) & MSE(22) & LSE(16) & HSE(18) & MSE(22) & LSE(10) & & & \\
\hline $\begin{array}{c}\text { Curricular } \\
\text { Merit position in } \\
\text { exams }\end{array}$ & $50.00(6)$ & $27.27(6)$ & - & $44.44(8)$ & $36.36(8)$ & - & $0.32^{\mathrm{NS}}$ & $0.64^{\mathrm{NS}}$ & - \\
\hline $\begin{array}{l}\text { Scholarship holders } \\
\text { Co-curricular } \\
\text { Dance }\end{array}$ & $33.33(4)$ & $09.09(2)$ & - & $33.33(6)$ & $09.09(2)$ & - & - & - & - \\
\hline Quiz & $33.33(4)$ & $18.18(4)$ & $12.50(2)$ & $27.77(5)$ & $27.27(6)$ & $10.00(1)$ & $0.35^{\mathrm{NS}}$ & $0.71^{\mathrm{NS}}$ & $0.16^{\mathrm{NS}}$ \\
\hline Singing & $16.66(2)$ & $36.36(8)$ & $12.50(2)$ & $22.22(4)$ & $40.90(9)$ & $20.00(2)$ & $0.41^{\mathrm{NS}}$ & $0.87^{\mathrm{NS}}$ & $0.53^{\mathrm{NS}}$ \\
\hline Painting & - & $09.09(2)$ & $12.50(2)$ & $16.66(3)$ & $09.09(2)$ & - & $1.85^{\mathrm{NS}}$ & - & $1.47^{\mathrm{NS}}$ \\
\hline Sports & $16.66(2)$ & $22.72(5)$ & $6.25(1)$ & $22.22(4)$ & $13.63(3)$ & $10.00(1)$ & $0.47^{\mathrm{NS}}$ & $0.79^{\mathrm{NS}}$ & $0.35^{\mathrm{NS}}$ \\
\hline None & $50.00(6)$ & $09.09(2)$ & $\begin{array}{c}- \\
8750(14)\end{array}$ & $33.33(6)$ & $18.18(4)$ & - & $0.93^{\mathrm{NS}}$ & $0.88^{\mathrm{NS}}$ & - \\
\hline & - & $40.90(9)$ & $87.50(14)$ & - & $31.18(7)$ & $80.00(8)$ & - & $0.62^{\mathrm{NS}}$ & $0.69^{\mathrm{Nos}}$ \\
\hline
\end{tabular}

Figures in parentheses indicate number of female students

NS- Non significant

Table 5 reflects the comparison between self esteem levels of PG female students and their special achievements in curricular and co-curricular domains. In low SES group 40 percent of PG female students having middle level of self esteem reported to have got merit positions in college followed by high level of self esteem (37\%) and low level of self esteem (nil\%) PG female students. Twenty eight percent of middle level self esteem PG female students were found to have received prizes in painting followed by sports (25\%), dance (19\%), quiz (16\%) and 
singing (3\%). On the other hand in middle SES group 43 percent of high level self esteem PG female students were found to have got merit positions in college and scholarships followed by middle level of self esteem PG female students (26\%) and none of the low level self esteem PG female students. Fifty seven percent of PG female students having high level self esteem reported to have got prizes in sports followed by painting (29\%) and dance \& quiz (14\%).

Table 5 Comparison between self esteem levels of the of postgraduate female students and their special achievements in curricular and co-curricular domain

\begin{tabular}{|c|c|c|c|c|c|c|c|c|c|}
\hline \multirow{4}{*}{$\begin{array}{c}\text { Special } \\
\text { achievements }\end{array}$} & \multicolumn{6}{|c|}{ SES, self esteem levels and percentage of the female students (100) } & \multirow{3}{*}{\multicolumn{3}{|c|}{ Z Values }} \\
\hline & \multirow{2}{*}{\multicolumn{3}{|c|}{$\begin{array}{c}\text { Low SES (50) } \\
\text { Self esteem levels }\end{array}$}} & \multirow{2}{*}{\multicolumn{3}{|c|}{$\begin{array}{c}\text { Middle SES }(\mathbf{5 0}) \\
\text { Self esteem levels }\end{array}$}} & & & \\
\hline & & & & & & & & & \\
\hline & $\operatorname{High}(8)$ & Middle(32) & $\operatorname{Low}(10)$ & High(7) & Middle(34) & $\operatorname{Low}(9)$ & a ved & hyse & c $f$ \\
\hline Curricular & & & & & & & & & \\
\hline $\begin{array}{l}\text { Merit position } \\
\text { in exams }\end{array}$ & $37.50(3)$ & $40.62(13)$ & - & $42.85(3)$ & $9(26.47)$ & - & $0.19^{\mathrm{NS}}$ & $1.22^{\mathrm{NS}}$ & - \\
\hline $\begin{array}{l}\text { Scholarship } \\
\text { holder }\end{array}$ & $37.50(3)$ & $03.12(1)$ & - & $42.85(3)$ & - & - & $0.19^{\mathrm{NS}}$ & $0.99^{\mathrm{NS}}$ & - \\
\hline $\begin{array}{l}\text { Co- } \\
\text { curricular }\end{array}$ & $25.00(2)$ & $18.75(6)$ & - & $14.28(1)$ & $23.52(8)$ & $11.11(1)$ & $0.54^{\mathrm{NS}}$ & $0.50^{\mathrm{NS}}$ & - \\
\hline Dance & $25.00(2)$ & $15.62(5)$ & $3(30.00)$ & $14.28(1)$ & $7(20.58)$ & - & $0.54^{\mathrm{NS}}$ & $0.53^{\mathrm{NS}}$ & $2.07 *$ \\
\hline Quiz & $12.50(1)$ & $03.12(3)$ & $20.00(2)$ & - & $08.82(3)$ & 11.11(1) & $1.04^{\mathrm{NS}}$ & $0.90^{\mathrm{NS}}$ & $0.54^{\mathrm{NS}}$ \\
\hline Singing & $12.50(1)$ & $28.12(9)$ & $20.00(2)$ & $28.57(2)$ & 29.41(10) & $22.22(2)$ & $0.78^{\mathrm{NS}}$ & $0.08^{\mathrm{NS}}$ & $0.10^{\mathrm{NS}}$ \\
\hline Painting & $50.00(4)$ & $25.00(8)$ & - & $57.14(4)$ & $52.94(8)$ & - & $0.27^{\mathrm{NS}}$ & $2.34 * *$ & - \\
\hline $\begin{array}{l}\text { Sports } \\
\text { None }\end{array}$ & - & $40.62(13)$ & $70.00(7)$ & - & $52.94(18)$ & 99.99(9) & - & $0.44^{\mathrm{NS}}$ & $1.95^{\mathrm{NS}}$ \\
\hline
\end{tabular}

Figures in parentheses indicate number of female students

NS- Non significant

\section{Reference}

[1]. Camphell J., Krueger J.I., Vohs K.D. and Baumeister R.F. 2003 Cited in the article on Does high self esteem cause better performance.

[2]. Francis and Jones 1996https://en.wikipedia.org/wiki/Self-esteem

[3]. Maruyana, Geoffrey M., Rubin, Rosalyn A., Kingsbury G. Gage 1981, Self esteem and educational achievement: Independent Consultant with a Common Cause, J of Personality and Social Psychology 40:5, PP. 962-975.

[4]. Rosenberg 1965 https://en.wikipedia.org/wiki/Self-esteem 